\title{
Author Correction: A quantitative analysis of 3D-cell distribution in regenerative muscle-skeletal system with synchrotron X-ray computed microtomography
}

\author{
Markéta Tesařová, Lucia Mancini, Andras Simon, Igor Adameyko, Markéta Kaucká (iD, \\ Ahmed Elewa, Gabriele Lanzafame iD, Yi Zhang, Dominika Kalasová, Bára Szarowská, \\ Tomáš Zikmund, Marie Novotná \& Jozef Kaiser (iD
}

Correction to: Scientific Reports https://doi.org/10.1038/s41598-018-32459-2, published online 20 September 2018

The original version of this Article contained an error in the title of the paper, where the word "regenerative" was incorrectly given as "regeneration".

Additionally, in the Results section under subheading 'Biological results',

"The muscles showed incremental growth during the regeneration process in coordination with expanding cartilage and also appeared with their corresponding attachment points at different timing."

now reads:

"The muscles showed incremental growth in coordination with expanding cartilage. Also, we show the attachment points of muscles during the developmental process."

"Our visualizations provided detailed information about developing joint surfaces at cellular resolution in 3D in the regenerating salamander limb."

now reads:

"Our visualizations provided detailed information about developing joint surfaces at cellular resolution in 3D in the regenerative salamander limb."

These errors have now been corrected in the PDF and HTML versions of the Article and in the accompanying Supplementary Information file.

(i) Open Access This article is licensed under a Creative Commons Attribution 4.0 International License, which permits use, sharing, adaptation, distribution and reproduction in any medium or format, as long as you give appropriate credit to the original author(s) and the source, provide a link to the Creative Commons license, and indicate if changes were made. The images or other third party material in this article are included in the article's Creative Commons license, unless indicated otherwise in a credit line to the material. If material is not included in the article's Creative Commons license and your intended use is not permitted by statutory regulation or exceeds the permitted use, you will need to obtain permission directly from the copyright holder. To view a copy of this license, visit http://creativecommons.org/licenses/by/4.0/.

(C) The Author(s) 2020 